\title{
Morphometric Analyses of Danxia Landforms in Relation to Bedrock Geology: A Case of Mt. Danxia, Guangdong Province, China
}

\author{
Wen Zhang ${ }^{1}$, Takashi Oguchi ${ }^{*}, 2$, Yuichi S. Hayakawa ${ }^{2}$ and Hua Peng ${ }^{3}$ \\ ${ }^{I}$ Department of Natural Environmental Studies, Graduate School of Frontier Sciences, The University of Tokyo, \\ Kashiwa, Japan \\ ${ }^{2}$ Center for Spatial Information Science, The University of Tokyo, Kashiwa, Japan \\ ${ }^{3}$ Department of Urban and Regional Planning, Sun Yat-sen University, Guangzhou, China
}

\begin{abstract}
The "Danxia landform" is an erosional landform type originally defined in China. It is characterized by redcolored sandstones and steep cliffs, and developed via long-term erosion. Detailed quantitative geomorphometric studies of the characteristics of Danxia landforms in China have not yet been conducted. Using GIS, we conducted DEM-based geomorphometric analyses of 42 watersheds on Mt. Danxia, China. This area has many typical Danxia landforms. Analysis of stream networks indicates that fault systems are responsible for the NE-trending stream direction. Hypsometric curves and hypsometric integrals $(H I)$ of the watersheds show that $H I$ is significantly affected by lithology; the lithological difference between the eastern and western parts of the study area are reflected in the general form of watersheds. Longitudinal profiles of the watersheds were used to analyze the stream length gradient $(S L)$ index and Hack profiles, which were also found to reflect lithology and fault control.
\end{abstract}

Keywords: Danxia landform, DEM, hypsometry, longitudinal profile, stream network, stream length gradient index, watershed.

\section{INTRODUCTION}

Chinese scholars have defined "Danxia landform," named for Mt. Danxia in Guandong Province, China, as a landform type made up of non-marine red clastic rock with nearly horizontal strata, red rock walls or cliffs and is relatively flat-topped. "Danxia landforms" were listed on the UNESCO World Natural Heritage list in 2010 because of their value as unique geomorphic landscapes. So far, geomorphological research on Danxia landforms has focused on the definition, classification, and qualitative description of the landforms and discussion about their origin (e.g. [1-4]) or small topographic configurations such as grooves [5]. Although lithological influences on the development of Danxia landforms have been suggested [1], this has not been confirmed by quantitative analysis of the landforms. Evolution of landforms can be inferred from morphometry, i.e., quantitative measurements of geomorphic properties. For example, drainage networks and river longitudinal profiles are widely used as indicators of geomorphological evolution in relation to lithology, base-level, and tectonics (e.g. [6-8]) because river channels are considered to be sensitive to environmental changes (e.g. $[9,10])$. Other geomorphic indices of watershed characteristics have also been used to identify the effects of external controls such as tectonics [11, 12]. Recent developments in geographic

*Address correspondence to this author at the Center for Spatial Information Science, The University of Tokyo, 5-1-5, Kashiwanoha, Kashiwa 277-8562, Japan; Tel: +81-4-7136-4291; Fax: +81-4-7136-4292;

E-mail: oguchi@csis.u-tokyo.ac.jp information systems (GIS) and digital elevation models (DEMs) have enabled flexible and efficient morphometric studies. This paper examines the stream net, river longitudinal profiles, and several geomorphic indices of watersheds in the Mt. Danxia region to investigate the influences of these geomorphological characteristics upon the formation of Danxia landforms.

\section{STUDY AREA}

Mt. Danxia, the site of the archetypal Danxia landforms, is located in the northeast of Shaoguan City, Guangdong Province, China $\left(24^{\circ} 51^{\prime} 48^{\prime \prime}-25^{\circ} 04^{\prime} 12^{\prime \prime} \mathrm{N}, 113^{\circ} 36^{\prime} 25^{\prime \prime}\right.$ $\left.113^{\circ} 47^{\prime} 53^{\prime \prime} \mathrm{E}\right)$ (Fig. 1). The prominent landform types in Mt. Danxia include more than 600 stony peaks, fortresses, walls, pillars (hoodoos), and natural bridges of various sizes and heights [2]. The elevation of Mt. Danxia ranges from 26 to $570 \mathrm{~m}$ a.s.l. Mt. Danxia lies in a subtropical zone with a monsoon climate; the mean annual temperature is $19.7^{\circ} \mathrm{C}$ and the mean annual precipitation is $1,715 \mathrm{~mm}$.

The study area is mainly underlain by Cretaceous red sandstone. Previous studies have described the geological evolution of the area $[13,14]$. The Himalayan orogeny that started ca. 23 Ma resulted in the uplift of Mt. Danxia, and the red sandstone beds have since been eroded by fluvial processes and mass movement. The Jinjiang and Zhenjiang rivers and their tributaries have had a strong influence on the geomorphology of Mt. Danxia (Fig. 1). We divided the study area into the western and eastern sides of the trunk streams of these two rivers (Fig. 1). Peng [2] suggested that five planar surfaces of different levels formed in Mt. Danxia due to the intermittent uplift. Several levels of fluvial terraces 
occur along the Jinjiang and Zhenjiang rivers. Their relative height above the present river bed varies from $\sim 11$ to $43 \mathrm{~m}$, and they have been dated as Late and Middle Pleistocene (ca. 29-518 ka) using the OSL dating method [15].

Fig. (1) shows the fault network and rock formations in the study area. According to Peng [16], the compressive early Yanshanian movement in the Middle Jurassic-Early Cretaceous resulted in two major structural components: 1)
NNE and NE trending faults, including the Renhua Fault, belonging to the Wuchuan-Sihui thrust fault belt, which has created a gradually westward-rising structure and 2) numerous E-W to NE-SW vertical joints in the red beds formed during the crustal movement. The NNE-trending faults underwent a left-lateral strike slip during the Cenozoic, controlling the strike of mountain ranges and development of intermontane basins [17]. The two major
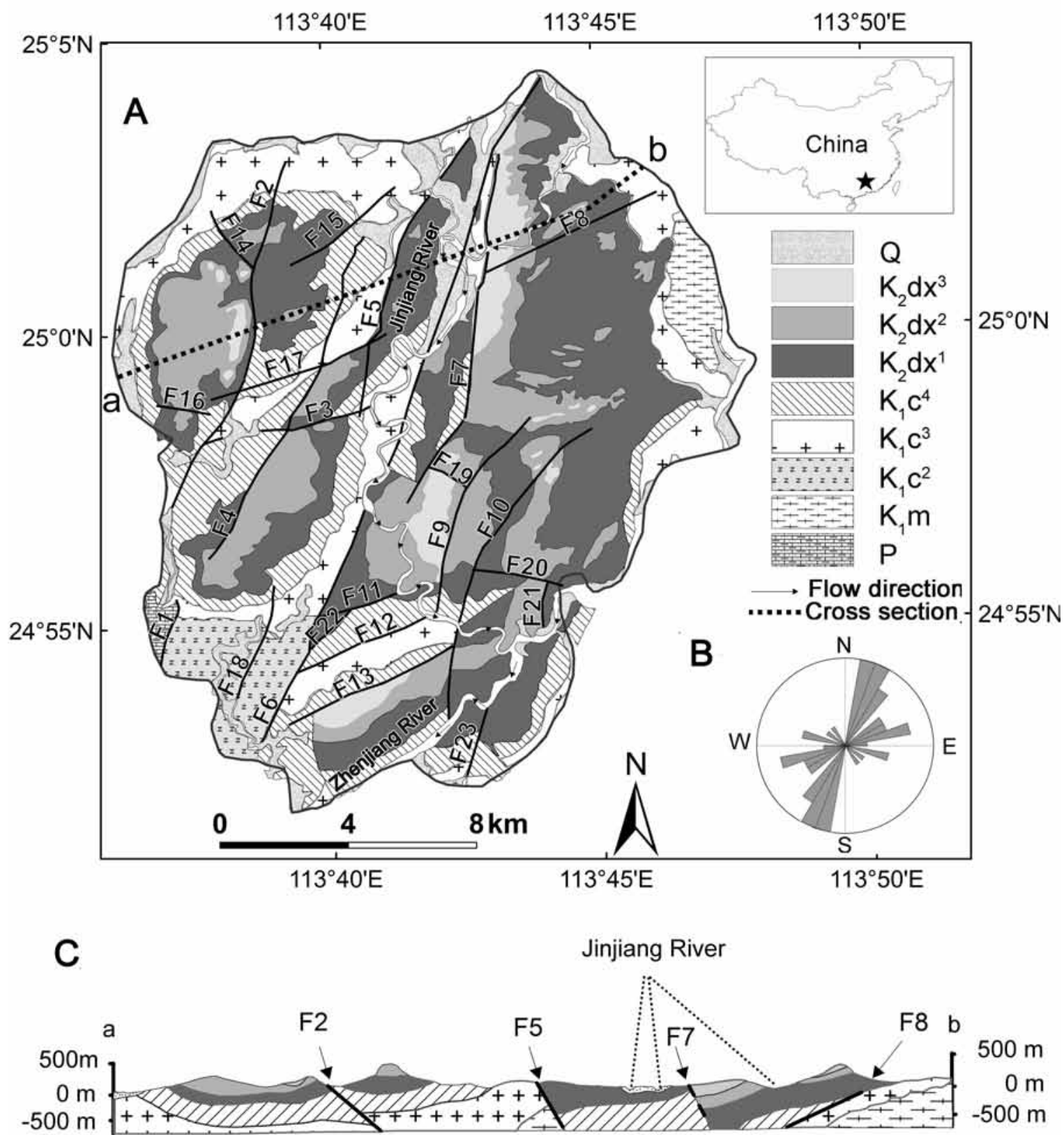

Fig. (1). Geology of the study area. (A) Geological map of the Mt. Danxia region showing main rock formations and faults. (B) Rose diagram showing fault orientations, based on GIS analysis of digitized fault lines. (C) Geological cross-section (location shown in A) showing the stratigraphic-structural relationship of the units. Q: Quaternary sediments, sand, pebble, rock block, silty soil and loam; $\mathrm{K}_{2} \mathrm{dx}{ }^{3}$ : $3^{\text {rd }}$ member of the Danxia Formation, brownish red interlaid conglomerate and medium arkose; $\mathrm{K}_{2} \mathrm{dx}^{2}: 2^{\text {nd }}$ member of the Danxia Formation, arkose, thin bedded silty mudstone, siltstone and conglomerate; $\mathrm{K}_{2} \mathrm{dx}^{1}: 1^{\text {st }}$ member of the Danxia Formation, brownish red conglomerate; $\mathrm{K}_{1} \mathrm{c}^{4}: 4^{\text {th }}$ member of the Changba Formation, purplish red thin to medium bedded muddy sandstone and siltstone; $\mathrm{K}_{1} \mathrm{c}^{3}: 3^{\text {rd }}$ member of the Changba Formation, purplish red complex conglomerate and sandy conglomerate; $\mathrm{K}_{1} \mathrm{c}^{2}: 2^{\text {nd }}$ member of the Changba Formation, purplish red siltstone and intercalated sandstone; $\mathrm{K}_{1} \mathrm{~m}$ : Maziping Formation, grayish white feldspathic quartz sandstone; P: Permian system, cherty limestone and mudstone. 
geological formations in Mt. Danxia are the older Changba Formation (130-100 Ma) and the younger Danxia Formation (100-70 Ma) (Fig. 1; [18, 19]). Both formations consist mainly of sandstones such as arkose. Archetypal Danxia landforms are found in red terrestrial sedimentary rocks of the Danxia Formation.

\section{MATERIALS AND METHODOLOGY}

The main source data for this study are the ASTER GDEM, a 1:50,000 topographic map, and a 1:50,000 geologic map (Fig. 1). The ASTER GDEM was provided by the Ministry of Economy, Trade, and Industry (METI) of Japan and the National Aeronautics and Space Administration (NASA) of the United States. We downloaded the DEM for the study area from the NASA web site and corrected it before incorporating it into the UTM projection to ensure uniform cell size $(30 \times 30 \mathrm{~m})$. The topographic map was published by the Sun Yat-Sen University, China, in 2008. The geologic map was published by the Guangdong Institute of Geological Survey, China, in 2000. Stream-nets and watersheds were extracted from the DEM using the method of threshold drainage area [20] embedded in the ArcHydro Tools of ESRI ArcGIS. By interpreting the plot of drainage density compared to contributing drainage area [21], the critical drainage area was determined to be $0.1 \mathrm{~km}^{2}$, which corresponds well to the actual stream network shown in the topographic map. The streams and watersheds were ordered based on the method of Strahler [22]. Forty-two 3rd order watersheds and their main streams were delineated. Among them, 26 watersheds are located on the eastern side, and 16 on the western side. The stream route between the headwater (highest point) and the lowest point in the watershed was regarded as the master stream. Basic morphometric properties of the watersheds such as area, mean slope, and the hypsometry, as well as the longitudinal profiles of the 42 main streams were also obtained.

The hypsometric curve and hypsometric integral $(H I)$ are useful in determining the stage of geomorphic development $[22,23]$. The curve is a plot of the relative height $(h / H)$ against the relative area $(a / A)$, where $H$ is the highest elevation of the watershed, $A$ is the total area of the watershed, and $a$ is the area of the watershed above a given elevation $h$ [22]. Convex-up hypsometric curves indicate relatively young watersheds; S-shaped curves characterize moderately eroded watersheds; and concave curves indicate relatively old watersheds $[11,24,25]$. $H I$ is a measure of the overall proportion of high and low areas inside a watershed:

$H I=\int_{\text {min elevation }}^{\text {max elevation }} \frac{a}{A} \times \Delta\left(\frac{h}{H}\right)$

The shape of the hypsometric curve and the $H I$ provide valuable information not only on the erosional stage of the watershed, but also on the tectonic and lithological factors controlling it (e.g. [26-28]). We obtained the hypsometric curves and $H I$ from the DEM using MathWorks Matlab.

The $S L$ index [29] enables the quantification of differences in erosion patterns between rivers. The $S L$ index is correlated with the stream power and is sensitive to variations in the river gradient:
$S L=(\Delta E / \Delta L) L$

where $\Delta E$ is the difference in elevation $(E)$ between the ends of the reach of interest, $\Delta L$ is the length of the reach, and $L$ is the horizontal length from the watershed divide to the midpoint of the reach. We calculated $S L$ at $120-\mathrm{m}$ intervals, yielding 1240 points for the calculation. We also followed the methodology proposed by Chen et al. [30] and produced the "Hack profile" and the idealized gradient index $(K)$ [29] for the entire profile of each main stream of the 3rd watershed. $K$ can be deemed as the proxy of stream power and is computed as:

$$
K=\frac{E_{i}-E_{j}}{\operatorname{In} L_{i}-\operatorname{In} L_{j}}
$$

where $i$ and $j$ refer to two points along the river profile.

A convex Hack profile suggests a river adjusting to fault movements and/or increasing rock resistance downstream, and a concave profile suggests a river adjusting to decreasing bedrock resistance downstream or significantly increasing discharge downstream [31, 32]. The theoretical equilibrium Hack profile is straight if a river is flowing across uniform bedrock [29, 33-35].

In addition to the $S L$ index and $H I$, we have also obtained commonly used two basic geomorphometric indices: relative relief and mean slope gradient for each watershed. Relative relief is defined here as the maximum elevation difference between the lowest and the highest points in a watershed [36].

Diagrams showing the D8 flow direction of streams for different orders were created to illustrate the distribution of stream orientation. To do this, stream orientation for each DEM cell was determined [20]. A similar technique was also applied to fault lines digitized from the geological map to show the trend in orientation of the faults. We also applied a 300-m buffer along each fault to objectively detect topographic elements adjacent to the faults.

\section{RESULTS AND DISCUSSION}

\section{Stream Orientation}

Fig. (2B) shows that the 1 st and 2 nd order streams tend to have flow directions of $\mathrm{E}, \mathrm{W}$, and $\mathrm{S}$, whereas the higher order streams tend to flow toward $\mathrm{S}$ to $\mathrm{SW}$. These approximately correspond to the fault orientation data in Fig. (1B); the larger higher-order streams follow the most distinct fault orientation (N-S to NE-SW), whereas the smaller lower-order streams additionally follow the second most distinct fault orientation (ENE-WSW). Such correlations between the stream and fault orientations, including data for streams that do not directly follow the major faults shown in Fig. (1), suggest the presence of numerous minor faults and fractures following the general structural trends of the major faults, and rivers tend to flow according to both the major and minor structural systems. Huang [15] pointed out the correlation between the N-S flowing Jinjiang River and the orientation of F6, and this study indicates such correlations are commonly found over the Mt. Danxia area, even on smaller scales. In addition, the large and small rivers are found to behave differently. The large rivers tend to follow 

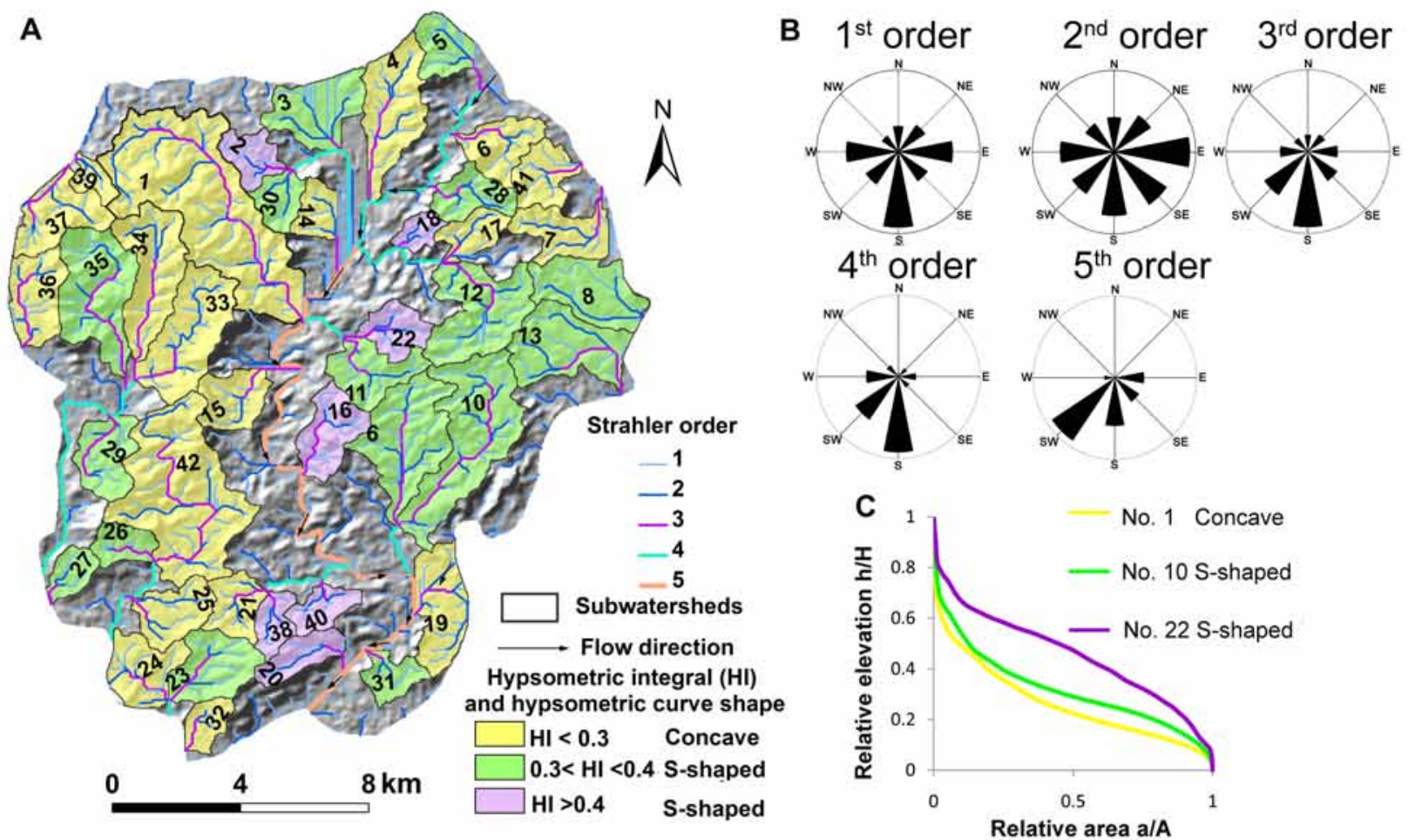

Fig. (2). Topographic characteristics of the study area. (A) Map showing watersheds and streams. Watersheds are numbered and classified according to their hypsometric integral $(H I)$ values. (B) Diagram showing the distribution of stream flow direction for different Strahler orders. Flow direction is shown for each DEM cell. (C) Representative hypsometric curves of the three types with different curve shapes and $H I$ values.

only the major structures like F6, while the small rivers flow more flexibly.

\section{Hypsometric Curves and the Hypsometric Integral (HI)}

The $H I$ values obtained for the 42 watersheds and some representative hypsometric curves are shown in Fig. (2A, C). $H I$ ranges between 0.21 and 0.57 with a mean of 0.32 . HI values can be grouped into three classes with respect to the convexity or concavity of the hypsometric curve: class 1 with concave curves $(H I<0.3)$; class 2 with S-shaped curves $(0.3 \leq H I<0.4)$; and class 3 with S-shaped curves $(H I \geq 0.4)$. The hypsometric curves and $H I$ values for the western and eastern sides display a marked difference. Watersheds with concave hypsometric curves and lower $H I$, representing a more mature topography, are located mostly on the western side, whereas watersheds with S-shaped curves and higher $H I$ with a less mature topography are mostly located on the eastern side. Because the population of $H I$ values is not normally distributed, we used the Kolmogorov-Smirnov nonparametric test method to evaluate the difference between the $H I$ values of the western and eastern sides [37, 38]. The result shows that the difference is statistically significant $(D=0.7778, p=0.008)$ (Table 1).

The difference between the eastern and western sides seems to result from lithological differences. The lithology of the eastern side is characterized mostly by the Danxia Formation, whereas that of the western side consists of a combination of the Changba and Danxia Formations (Fig. 1).
Table 1. Statistical Differences and Kolmogorov-Smirnov Test for HI Values in the Western and Eastern Sides

\begin{tabular}{|c|c|c|}
\hline & Western Side & Eastern Side \\
\hline \hline Number & 26 & 16 \\
\hline Mean & 0.29 & 0.38 \\
\hline Standard Deviation & 0.082 & 0.092 \\
\hline Minimum & 0.21 & 0.28 \\
\hline Maximum & 0.50 & 0.57 \\
\hline Standard Error of Mean & 0.016 & 0.023 \\
\hline Skewness & 1.12 & 0.93 \\
\hline Kurtosis & 1.04 & 0.21 \\
\hline$p$-Value & \multicolumn{2}{|c}{0.008} \\
\hline$D$ & \multicolumn{2}{|c}{0.7778} \\
\hline
\end{tabular}

On the western side, the Danxia Formation often exhibits steeper escarpments because it is more resistant to erosion than the Changba Formation [15, 16]. Zhu et al. [5] also suggest that the Changba Formation is more susceptible to freeze-thaw action than the Danxia Formation, which may have been an important erosion process during glacial periods. Therefore, the more resistant Danxia Formation seems to account for the less eroded topography of the eastern side, characterized by higher $H I$ values. 
The correlation between watershed hypsometry and the rock types can be presented more quantitatively. Class 1 with low $H I$ occupies $28.6 \%$ of the watersheds underlain mainly by the Changba Formation, in contrast to $16.6 \%$ underlain mainly by the Danxia formation. For Class 2 with intermediate $H I$, the ratios are $16.7 \%$ and $21.5 \%$, respectively; for Class 3 with high $\mathrm{HI}$, the ratios are $4.7 \%$ and $11.9 \%$, respectively. In other words, the relative abundance of the watersheds underlain mainly by the Changba Formation tends to decrease with increasing HI. It can be also noted that the distribution of the Class 3 watersheds (Fig. 2A) tends to correspond to less dissected topography underlain by the uppermost member of the Danxia Formation $\left(\mathrm{K}_{2} \mathrm{dx}^{3}\right.$ in Fig. 1). This observation suggests that the markedly resistant member of the Danxia Formation acts as a cap rock, preventing deep erosion (see the right side of Fig. 1C). Therefore, we conclude that watershed hypsometry in Mt. Danxia strongly reflects the bedrock's resistance to erosion. This agrees with the findings of Walcott and Summerfield [39], who found a strong correlation between $H I$ and bedrock resistance in the passive margin of southeast Africa. Mt. Danxia is also located in a passive margin with no records of recent intense seismic and tectonic activities. Even in the long term, the low relative heights of the Middle Pleistocene river terraces $(<50 \mathrm{~m})$ in
Mt Danxia indicate limited tectonic uplift. The effect of lithology on landforms seems to be more distinct in passive margins compared with tectonically active areas.

However, the effects of tectonics on the topography of Mt. Danxia cannot be ruled out completely. Although the watersheds in the western side are characterized by more advanced erosion in terms of hypsometry, the mean watershed elevation tends to be higher on the western side ( $\sim 60$ a.s.1.) than the eastern side $(\sim 130 \mathrm{~m}$ a.s.1.). This phenomenon may be caused by the relative uplift of the western side due to the slow but long-term activity of the F6 under NE-SW tectonic compression [40, 41].

\section{$S L$ and Hack Profiles}

The measured $S L$ values range from 0.2 to $992.7 \mathrm{~m}$, with a mean of $66.7 \mathrm{~m}$ and a standard deviation of $94.9 \mathrm{~m}$. The majority of the study reaches $(80 \%)$ show $S L$ smaller than $100 \mathrm{~m}$. The values were grouped into four classes according to the size of the standard deviation: 0-100, 101-250, 251350 , and $>351 \mathrm{~m}$ (Fig. 3). The classes of $S L>250 \mathrm{~m}$ can be regarded as anomalously high because they only appear in $3.1 \%$ of all reaches. They are often found in the lowermost reaches in a watershed (Fig. 4).

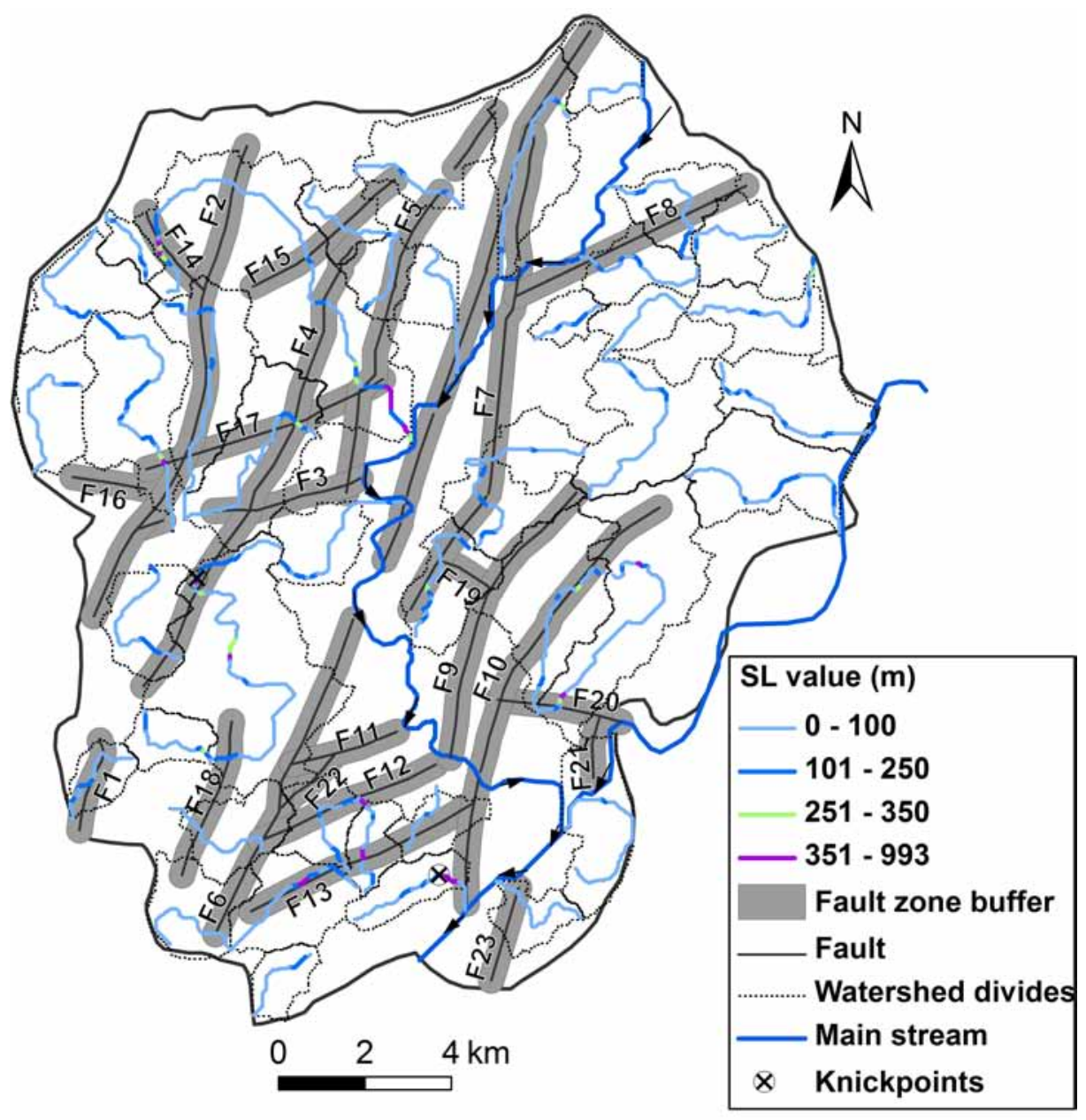

Fig. (3). Spatial distribution of $S L$ along the tributaries of the main stream (Jinjiang and Zhenjiang rivers) showing faults, buffers along the faults and watershed divides. 
A: western side
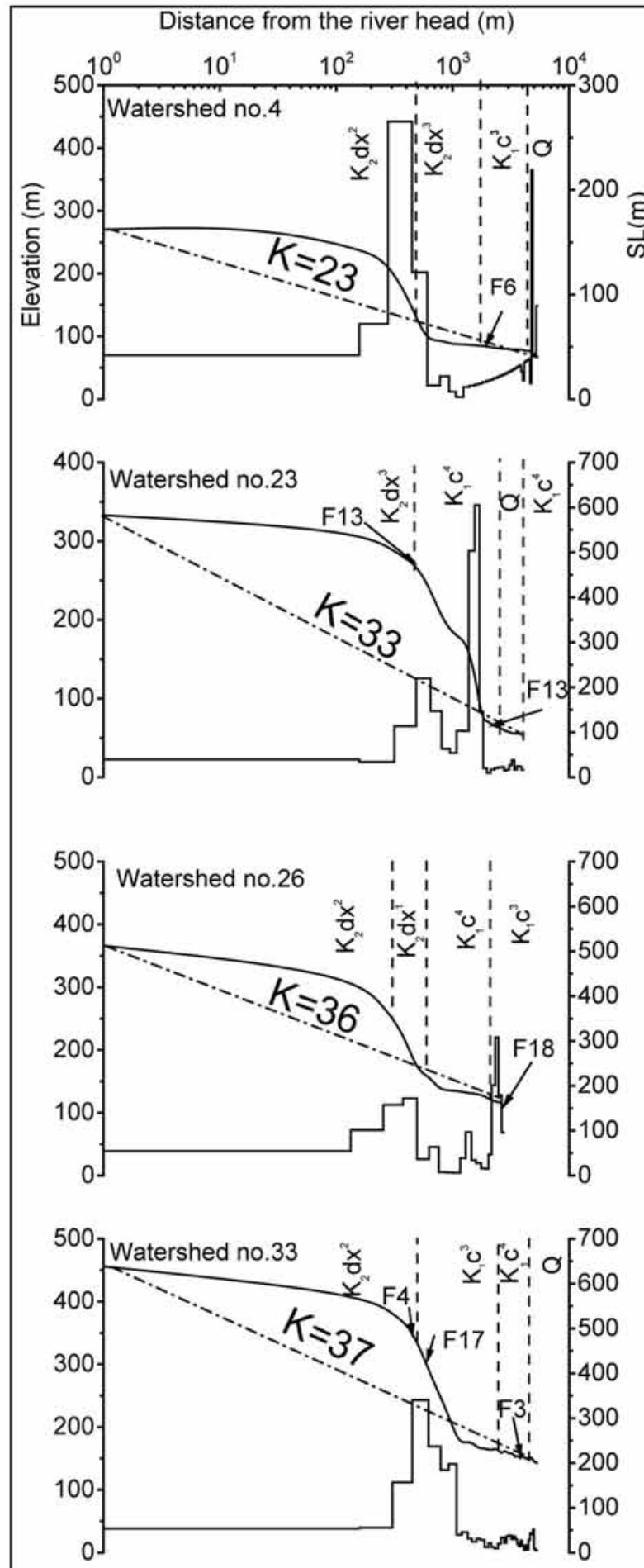

B:eastern side
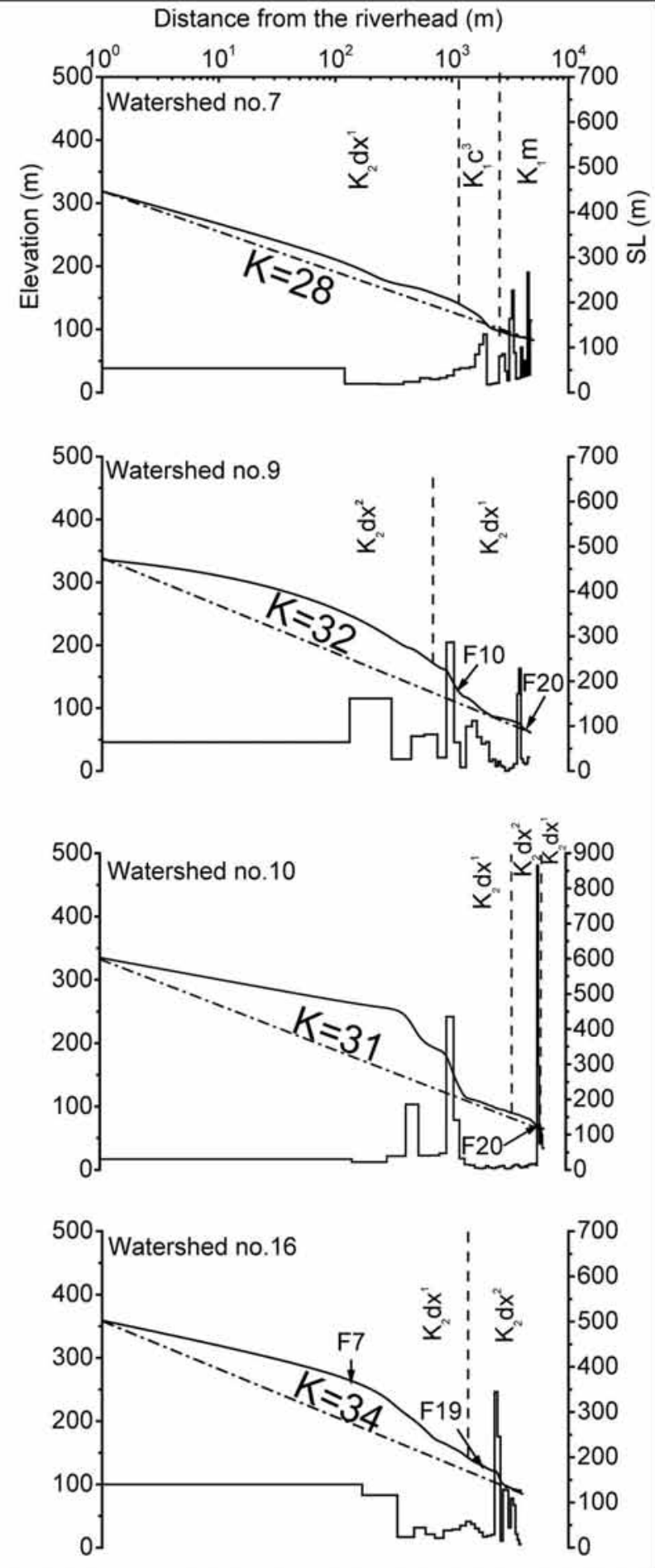

Fig. (4). Examples of Hack profiles (semilog plot of distance versus elevation along a river) in the western side (A) and the eastern side (B) with step $S L$ curves and overall $K$ values. The dashed line shows the equilibrium profile of each tributary. Fault numbers such as F6 correspond to those in Fig. (1). Vertical dotted lines show rock boundaries; see Fig. (1) for rock formation symbols. 
$S L$ differs according to lithology. Fig. (5) summarizes $S L$ values for the three major rock types along river reaches in the study area: the Danxia and Changba Formations, and the Quaternary sediments. Although the range of data is large, the order of mean or modal $S L$ values corresponds to the level of rock resistance, and the Kruskal-Wallis test has shown that the difference is statistically significant $(p<$ 0.001). Consequently, not only drainage watershed topography, as represented by hypsometry, but also channel forms are affected by lithology.

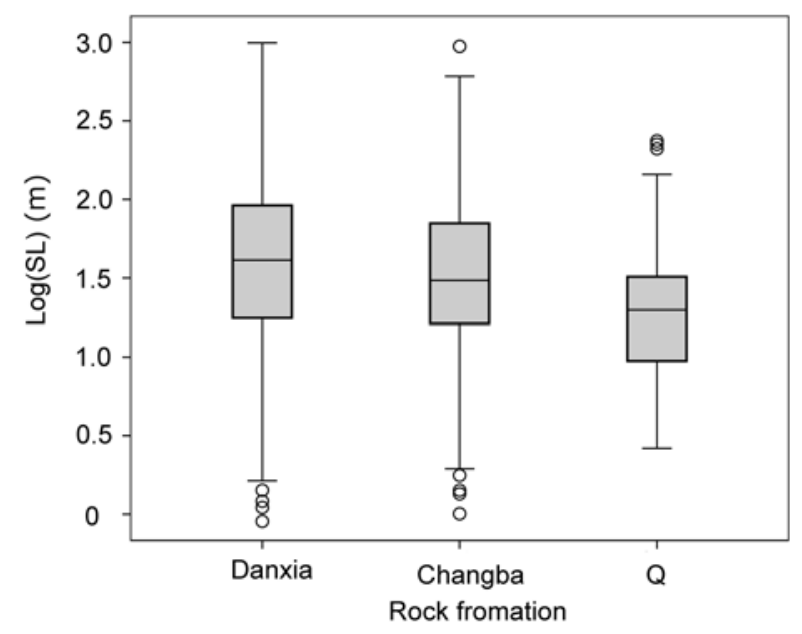

Fig. (5). Box plots of logarithmic values of $S L$ for the three major rock types. The difference between the rock types is significant based on the Kruskal-Wallis test $(p<0.001)$.

However, the average $S L$ value for the western side (70.7 $\mathrm{m})$ is slightly larger than that for the eastern side $(52.7 \mathrm{~m})$, although the areal ratio of the Changba Formation to the Danxia Formation is apparently higher on the western side (Fig. 1). The difference in the average $S L$ between the western and eastern sides is statistically significant according to the Kolmogorov-Smirnov test $(D=0.1128, p=0.001)$. This may be related to more heterogeneous lithology in the western side. Visual comparison of Figs. $(\mathbf{1}, \mathbf{3})$ indicates that $S L$ tends to be higher at the boundary of the Danxia and Changba Formations, because the local slope gradient tends to be high due to the deeper incision in the lower, more erodible Changba Formation. The effect of lithology on $S L$ is also supported by the Hack profiles. On the western side, the Hack profiles tend to show a markedly convex shape (Fig. 4A), which seems to reflect the transition from the more resistant Danxia Formation to the less resistant Changba Formation. However, most major rivers in the eastern side show less convex Hack profiles (Fig. 4B), reflecting the homogeneity of the bedrock. The average $K$ value for the western side (28.3) is slightly higher than that for the eastern side (25.0), suggesting that the lithological contrasts in the western side led to somewhat steeper reaches. Our results agree with Duvall et al. [7] who indicated streams flowing from resistant to less resistant bedrock exhibit highly concave profiles and increased gradients along their lower reaches. In addition, VanLaningham et al. [43] noted that rivers on more resistant rocks have lower longitudinal concavity.
In addition, some locally high $S L$ values correspond to faults, rather than rock boundaries, e.g., Watersheds 4 (F6), 23 (F13), 26 (F18), and 33 (F4 and F17) of the western side (Figs. 3, 4A). As shown in Fig. (3), waterfall-type knickpoints are observed in watersheds 20 and 42 [15]. These knickpoints are also located close to the faults, and correspond with locally high $S L$ values, as indicated elsewhere [35, 42]. The influence of the faults on $S L$ is also shown by the buffer analysis: $48 \%$ of anomalously high $S L$ values are located within the buffer zones along the major faults. The distribution of faults is much denser in the western side (Fig. 1), which may account for the relatively higher $S L$ values in this region.

However, some anomalously high $S L$ values correspond to neither rock boundaries nor the major faults e.g. Watersheds 9, 10, and 16 in the eastern sector (Fig. 4B). The Hack profiles also sometimes show local concavity within a single rock type, as for Watershed 10 (Fig. 4B). Further studies are needed to inquire into the causes of such anomalies.

\section{Validation of Discussion in Terms of Correlations Between the Parameters}

The average values of relative relief and slope gradient for the western side $\left(303.9 \mathrm{~m}, 11.03^{\circ}\right)$ are slightly larger than those for the eastern side $\left(265.2 \mathrm{~m}, 10.7^{\circ}\right)$, which corresponds to the higher $S L$ and $K$ values in the western side. To examine such correspondences, we investigated the relationship between the slope gradient, relative relief, $H I$, $S L$ and $K$ (Fig. 6). $S L$ and $K$ have significant linear correlations with relative relief and slope gradient (Figs. 6A, $\mathbf{B}, \mathbf{D}, \mathbf{E}$ ), but not with $H I$ (Figs. 6C, F). Therefore, the previous discussion on $H I$ and that on $S L$ and $K$ can be regarded as independent and thus both are valid. To summarize, the two sides of study area have experienced different erosional processes due mainly to lithology and structural control.

\section{CONCLUSIONS}

This paper compared a DEM with geological data and discussed the effects of lithology and bedrock structures on landforms in Mt. Danxia, China. The courses of streams are strongly influenced by bedrock structures represented by the orientations of faults. Higher order streams tend to follow the major fault structures whereas lower order streams follow both major and minor structures. General watershed shapes represented by the hypsometric curves and $H I$, as well as longitudinal characteristics represented by the Hack profiles and $S L$, also reflect the lithology and structure of bedrock. Therefore, differences in rock types and fault distribution account for the topographical differences between the western and eastern parts of the study area. In spite of some topographic anomalies unrelated to bedrock characteristics and the possible influence of tectonics on the height distribution in the western and eastern regions of Mt. Danxia, bedrock characteristics play a major role in determining the landforms of this area. Although it has often been suggested that Danxia landforms with steep valley sides and relatively flat ridges indicate the red sandstone bedrock geology, this study has shown that other geologic variations, including different sandstone formations, affect the overall watershed forms and river longitudinal profiles. 


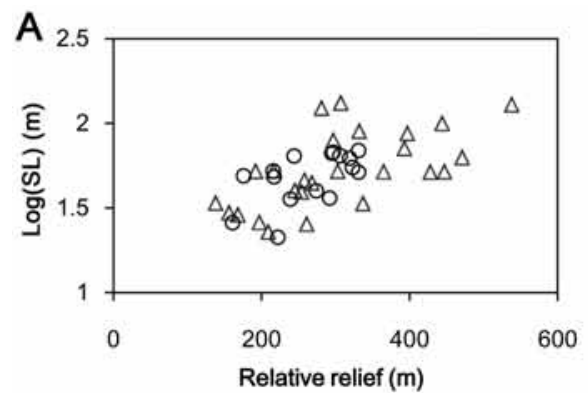

Kendall's rank correlation tau $=0.45$

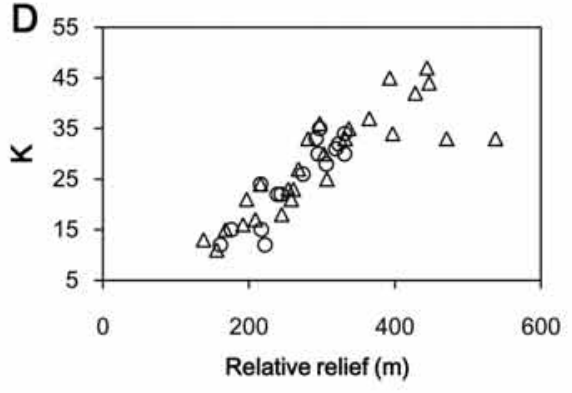

Kendall's rank correlation tau $=0.75$

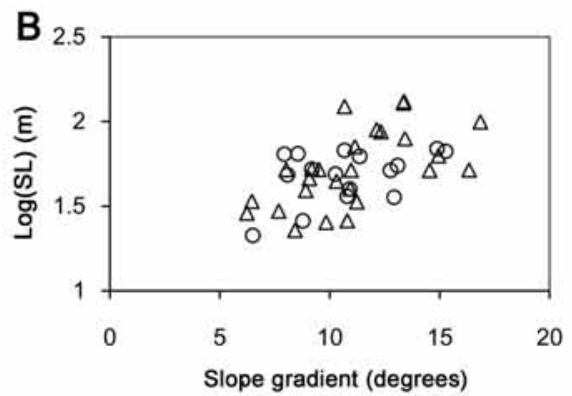

Kendall's rank correlation tau $=0.37$

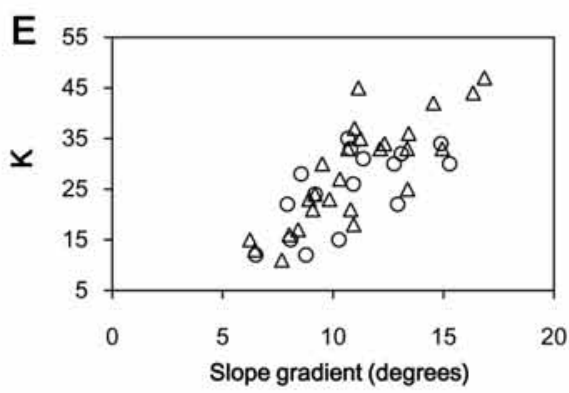

Kendall's rank correlation tau $=0.55$

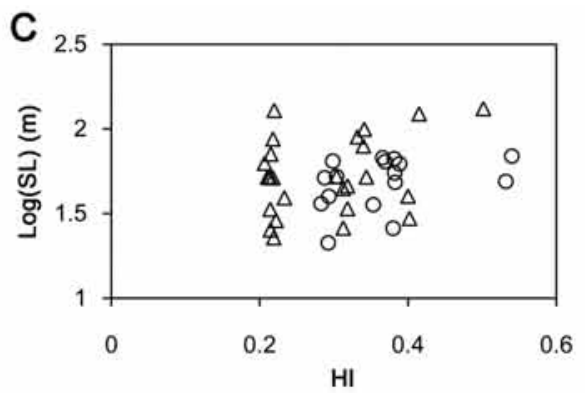

Kendall's rank correlation tau $=0.10$

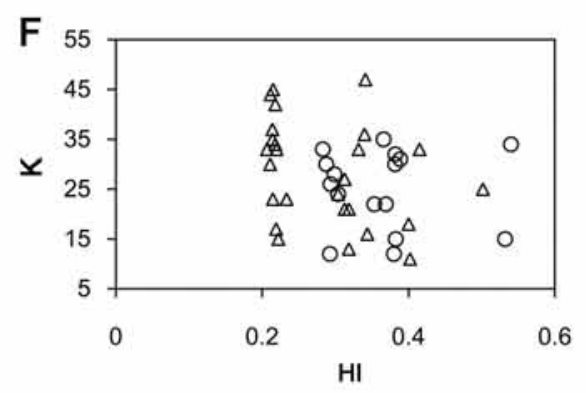

Kendall's rank correlation tau $=-0.24$

Fig. (6). Relationships of $S L$ and $K$ with topographic indices. (A) $S L$ versus relative relief, (B) $S L$ versus slope gradient, (C) $S L$ versus $H I$, (D) $K$ versus relative relief, (E) $K$ versus slope gradient, (F) $K$ versus $H I$. Triangles: western side; Circles: eastern side.

\section{CONFLICT OF INTEREST}

The authors confirm that this article content has no conflict of interest.

\section{ACKNOWLEDGEMENTS}

We thank Ms. Fang Ren at Saint Louis University for her helpful suggestion about data collection and analysis. We also thank two anonymous reviewers for their useful comments. This work was supported by JSPS KAKENHI Grant Number 23501237.

\section{REFERENCES}

[1] Huang J. Research report on Danxia Landform in China. Trop Geogr 1992; (Suppl.): 1-36, (in Chinese).

[2] Peng H. Danxia geomorphology of China: A review. Chin Sci Bull 2001; 46 (Suppl. 1): 38-44.

[3] Ouyang J, Zhu C, Peng H, et al. Types and spatial combinations of Danxia landform of Fangyan in Zhejiang Province. J Geogr Sci 2009; 19: 631-640.

[4] Kusky TM, Ye MH, Wang JP, Wang L. Geological evolution of longhushan world geopark in relation to global tectonics. J Earth Sci 2010; 21: 1-18.

[5] Zhu C, Peng H, Ouyang J, Hu Z, Li L. Rock resistance and the development of horizontal grooves on Danxia slopes. Geomorphology 2010; 123: 84-96.

[6] Clark MK, Schoenbohm LM, Royden LH, et al. Surface uplift, tectonics, and erosion of eastern Tibet from large-scale drainage patterns. Tectonics 2004; 23: TC1006.

[7] Duvall A, Kirby E, Burbank D. Tectonic and lithologic controls on bedrock channel profiles and processes in coastal California. J Geophys Res 2004; 109: F03002.

[8] Goldrick G, Bishop P. Regional analysis of bedrock stream long profiles: evaluation of Hacks SL form, and formulation and assessment of an alternative (the DS form). Earth Surf Procss Landforms 2007; 32: 649-71.

[9] Whipple KX, Tucker GE. Dynamics of the stream-power river incision model: Implications for height limits of mountain ranges, landscape response timescales, and research needs. J Geophys Res Solid Earth 1999; 104: 17661-74.
[10] Korup O. Rock-slope failure and the river long profile. Geology 2006; 34: 45-8.

[11] Keller EA, Pinter, N. Active Tectonics: Earthquakes, Uplift, and Landscape (second edition). Englewood Cliffs, New Jersey: Prentice Hall 2002.

[12] Pedrera A, Perez-Pena JV, Galindo-Zaldívar J, Azañón JM, Azor A. Testing the sensitivity of geomorphic indices in areas of lowrate active folding (eastern Betic Cordillera, Spain). Geomorphology 2009; 105: 218-31.

[13] Wu QJ. Basic geologic features of Danxia basin. Econ Geogr 1994; 14: $1-21$.

[14] Huang J. Quantitative survey of several important issues concerning with the formation of the Danxia landforms. Trop Geogr 2004; 24:123-6. (in Chinese)

[15] Huang J. Danxiashan Landform. Beijing: Science Press 2010.

[16] Peng H. Danxia Geomorphology of China and its Progress in Research Work. Guangzhou: Sun Yat-Sen University Press 2000. (in Chinese).

[17] Shu LS, Zhou XM, Deng P, Wang B, Jiang SY, Yu JH. Mesozoic tectonic evolution of the Southeast China Block: New insights from basin analysis. J Asian Earth Sci 2009; 34(3): 376-91.

[18] Huang J, Chen ZJ. The discussion on the definition and classification to Danxia landform. Econ Geogr 2003; 23(Suppl.): 611.

[19] Peng H, Wu Zh. A preliminary study on the characteristics and the distribution of red beds. Acta Sci Nat Univ Sunyatseni 2003; 42: 109-13. (in Chinese)

[20] Jenson SK, Domingue JO. Extracting topographic structure from digital elevation data for geographic information system analysis. Photogramm Eng Rem Sens 1988; 54:1593-600.

[21] Pallard B, Castellarin A, Montanari A. A look at the links between drainage density and flood statistics. Hydrol Earth Syst Sci 2009; 13: $1019-29$.

[22] Strahler AN. Hypsometric (area-altitude) analysis of erosional topography. Geol Soc Am Bull 1952; 63: 1117-42.

[23] Gardner TW, Sasowskky KC, Day RL. Automated extraction of geomorphometric properties from digital data. Z Geomorpholo, Supplement Band 1990; 80: 57-68.

[24] Strahler AN. Quantitative analysis of watershed geomorphology. Trans Am Geophys Union 1957; 38: 913-20.

[25] Delcaillau B, Deffontaines B, Floissac L, Angelier J, Deramond J, Souquet P, Chu HT, Lee JF. Morphotectonic evidence from lateral 
propagation of active frontal fold; Pakuashan anticline, foothills of Taiwan. Geomorphology 1998; 24: 263-90.

[26] Moglen GE, Bras RL. The effect of spatial heterogeneities on geomorphic expression in a model of basin evolution. Water Resour Res 1995; 31: 2613-23.

[27] Willgoose G, Hancock G. Revisiting the hypsometric curve as an indicator of form and process in transport-limited catchment. Earth Surf Processes Landforms 1998; 23: 611-23.

[28] Huang XJ, Niemann JD. An evaluation of the geomorphically effective event for fluvial processes over long periods. J Geophys Res 2006; 111: F03015.

[29] Hack JT. Stream profile analysis and stream gradient index. J Res US Geo Surv 1973; 1: 421-9.

[30] Chen YC, Sung Q, Cheng K. Along-strike variations of morphotectonic features in the Western Foothills of Taiwan: tectonic implications based on stream gradient and hypsometric analysis. Geomorphology 2003; 56: 109-37.

[31] DeGraff JV. A stream-gradient index applied to subhumid montane streams. Phys Geogr 1981; 2: 174-83.

[32] Harkins NW, Anastasio DJ, Pazzaglia FJ. Tectonic geomorphology of the Red Rock fault, insights into segmentation and landscape evolution of a developing range front normal fault. J Struct Geol 2005; 27: 1925-34.

[33] Hack JT. Physiographic division and differential uplift in the Piedmont and Blue Ridge. U.S. Geol. Surv 1982; Prof. Pap.1265: $1-49$.

[34] Merritts D, Vincent KR. Geomorphic response of coastal stream to low, intermediate, and high rates of uplift, Mendocino triplfe junction region, northern California. Geol Soc Am Bull 1989; 101: 1373-88.
[35] Brookfield, ME. The evolution of the great river systems of southern Asia during the Cenozoic India-Asia collision: rivers draining southwards. Geomorphology 1998; 22: 285-312.

[36] Hadley RF, Schumm SA. Sediment sources and drainage basin characteristics in upper Cheyenne river basin. US Geol Surv watersupply paper 1961;1531-B:137-196.

[37] Davis JC, Statistics and Data Analysis in Geology. New York: Wiley 1986.

[38] Snyder NP, Whipple KX, Tucker GE, Merrits DJ. Channel response to tectonic forcing: field analysis of stream morphology and hydrology in the Mendocino triple junction region, northern California. Geomorphology 2003; 53: 97-127.

[39] Walcott RC, Summerfield MA. Scale dependence of hypsometric integrals: an analysis of southeast African basins. Geomorphology 2007; 96: 174-86.

[40] Zhang HN, Ji FJ. A study on the recent activity along the southern segment of WuChuan-Sihui fault zone. Seismol Geol 1995; 17: 419-426 (in Chinese).

[41] Zhang ZJ, Wang YH. Crustal structure and contact relationship revealed from deep seismic sounding data in South China. Phys Earth Planet Inter 2007; 165: 114-26.

[42] Štěpančíková, P, Štemberk, J, Vilímek, V, Košt'ak, B. Neotectonic development of drainage network in the East Sudeten Mountains and monitoring of recent displacements (Czech Republic). Geomorphology 2008; 102: 68-80.

[43] VanLaningham S, Meigs A, Goldfinger C. The effects of rock uplift and rock resistance on river morphology in a subduction zone forearc, Oregon, USA. Earth Surf Processes Landforms 2006; 31 : 1257-79

(C) Zhang et al.; Licensee Bentham Open.

This is an open access article licensed under the terms of the Creative Commons Attribution Non-Commercial License (http://creativecommons.org/licenses/by$\mathrm{nc} / 3.0 /$ ) which permits unrestricted, non-commercial use, distribution and reproduction in any medium, provided the work is properly cited. 